\title{
Disease Recording Systems and Herd Health Schemes for Production Diseases
}

\author{
By S-O.Olsson ${ }^{1}$, P. Baekbo ${ }^{2}$, S.Ö. Hansson ${ }^{3}, H$. Rautala $^{4}$ and O. Østerås ${ }^{5}$ \\ ${ }^{1}$ Swedish Dairy Association, S-631 84 Eskilstuna, Sweden, ${ }^{2}$ Danish Bacon and Meat Council, P.O. Box 50, DK- \\ 8620 Kjellerup, Denmark, ${ }^{3}$ Veterinary Services, Sölvhólsgata 7, IS-150 Reykjavik, Iceland, ${ }^{4}$ Finnish Animal \\ Breeding Association (FABA), P.O. Box 40, FIN-01301 Vantaa, Finland, ${ }^{5}$ TINE Norwegian Dairies, P.O. Box 58, \\ NO-1430 Ås, Norway.
}

\begin{abstract}
Disease recording of cattle is compulsory in Sweden and Norway. Sweden and Denmark also have mandatory disease recording for swine, whereas Finland and Norway only have compulsory recording of infectious diseases. Both compulsory and voluntary systems are databased, the first ones developed in the 1970's.

Disease recording at pig slaughtering is somewhat older. The veterinary practitioner, and often also the farmer, can report treated cases as well as fertility disturbances to the systems. Disease recording at slaughter is carried out by veterinarians and inspection officers. The databases are handled by the veterinary authorities or the agricultural organisations in each country. Costs are defrayed by the authorities and/or the agricultural industry. The farmers receive periodic reports. Data are stored for three to ten years, often longer. Affiliation to animal health schemes for cattle or swine is voluntary. In Sweden and Denmark (cattle) they are run within the scope of government regulations. Affiliation to animal health programmes may also be demanded by organisations within the agricultural industry. These organisations are also responsible for the administration of the program-mes. Costs to take part in herd health schemes are covered by the farmers them-selves. In certain cases, grants are received from agricultural organisations, authorities, or the European Union. Recording of diseases and the format of animal health schemes in the Nordic countries are described here in order to illustrate the possibilities to compare data between countries.
\end{abstract}

disease recording, herd health, production diseases, cattle, swine, Nordic countries.

\section{Introduction}

Modern computer processing has increased the possibilities to record, compile, and evaluate disease data, e.g. for the investigation of health problems. Disease recording and design of animal health schemes for cattle and swine in the Nordic countries are described in this article in order to illustrate the possibilities to com-pare data between different countries. A comparison of certain data concerning dairy cattle in Sweden, Denmark, Finland, and Norway has previously been presented (Plym Forshell et al, 1995). These data are continuously being up- dated by the Nordic Dairy Association's Committee for Milk Quality (NMSM).

\section{Cattle}

\section{Disease Recording Systems}

Organisation

Disease recording is compulsory in Sweden and Norway. Denmark has a voluntary system based on an agreement between the National Committee on Cattle Husbandry and the Danish Veterinary Association. Also Finland has a voluntary system, whereas Iceland has no 
recording system similar to for instance the Norwegian "helsekort" (health card).

Computerised recording systems were introduced in Norway already in 1975/76, and in Sweden and Finland in 1982. In Denmark a project was launched in 1990, which was extended and made voluntary in 1991. Sweden, Finland and Norway also have computerised recording systems for AI services. In Sweden the National Board of Agriculture introduced a new computer system in 1999 for the recording of diagnoses and treatments as well as registration of medical preparations with withdrawal periods for treatment of food producing animals. The latest revision of the Norwegian health card system was done in 1999. Among other things, the possibility was then introduced to record type of treatment (conventional or alternative treatment).

In all countries, recordings are made both of treated cases of diseases and fertility disturbances.

The veterinarians are responsible for the recordings. Using special codes, farmers in Sweden, Finland and Norway can also report data to their respective systems. Furthermore, Swedish and Finnish farmers are to keep journals of treatments of food producing animals involving the use of drugs with withdrawal times. Compulsory drug recording will also be introduced in Denmark. Norway has a special treatment certificate for drugs with withdrawal periods, which must be kept for two years.

As from 1999, the National Board of Agriculture is responsible for the Swedish database. Disease data are transferred weekly to the database for milk-recording, administered by the Swedish Dairy Association. In Denmark, all data are compiled in one database, handled by the National Committee on Cattle Husbandry. Data on animal diseases are transferred daily to this database from the veterinary invoicing system. The Agricultural Data Processing Centre is in charge of the Finnish database. TINE Norwegian Dairies handles a database containing production records, laboratory results and diseases (excluding diseases in groups $\mathrm{A}$ and $\mathrm{B}$ according to OIE classification).

Costs for these respective databases are defrayed in Sweden by the National Board of Agriculture and the Swedish Dairy Association; in Denmark by the National Committee on Cattle Husbandry; in Finland by FABA together with the AI and milk-recording organisations; and in Norway by the farmers and the National Veterinary Authorities.

\section{Data Input and Feedback Frequency}

In Sweden, veterinarians must report treatments within one week. Reporting to the invoicing system in Denmark varies between veterinarians from daily to once a month. In Finland the AI technicians transfer disease data from the cow's health card when visiting the herd. Twice a year they also go through all health cards in the herd. In Norway health card data are reported monthly through the milkrecording system. However, diseases according to groups A and B are reported without delay to the official district veterinarian, who in turn reports to the National Veterinary Authorities.

In Sweden, data on animal health and artificial inseminations are stored for a minimum of three and five years, respectively. In Denmark all data have been kept since the project was initiated in 1990. Data from the two previous years are stored in Finland, meaning that by the end of a year there are easily accessible data available for the latest three-year period. For research and other special purposes, data have been stored since 1982. In Norway, records are kept for ten years, and stored data are available from 1979. Swedish farmers receive monthly milk-recording reports plus one annual report. The National Board of Agriculture reports to the veterinary practitioners. In 1999 animal disease 
data will be accessible to all veterinarians via the Board of Agriculture's Internet Homepage. There will be a number of different qualification levels. After written permission from the farmer, the veterinarians in Denmark may get access to raw data or fixed printouts. Finnish farmers receive reports twice a year, and veterinarians get annual accounts. In Norway the farmers receive reports every second month as a rolling twelve-month report, and also an annual account. Veterinarians and advisory officers employed by TINE Norwegian Dairies receive annual statements of disease frequencies per herd within their region.

\section{Herd Health Schemes \\ Organisation}

Herd health schemes in Sweden are based on regulations issued by the Board of Agriculture, but affiliation is voluntary. Animal health services in Denmark are implemented by legislation. Iceland offers no organised programme. Animal health schemes in Finland and Norway are developed and run on a voluntary basis.

An animal health programme has been available in Sweden since the early 1970's, based on cell count in bulk milk and udder total milk samples, animal disease data, and reproduction data. This scheme is continuously being extended and improved, and has recently developed into a co-operation project between the Swedish Dairy Association and the Board of Agriculture. Farmers and veterinarians in Denmark can enter into agreements on animal health services also without disease recording. Such disease recording is however necessary to make the advisory work meaningful. The first development project in Finland was initiated in 1998. Norway has had animal health schemes since the middle of the 1970's.

Affiliation is not only motivated by legislation, but also by the need for quality assurance and/or production certification. A general con- ception is that prevention is better than disease therapy.

The Swedish animal health schemes are administered by the Swedish Dairy Association, and in Finland and Norway by the dairy organisations in the respective countries. According to Danish regulations, the Danish veterinarians are responsible for advisory work in the field of animal health.

Costs to participate in a herd health scheme are defrayed by the farmers in Sweden, Denmark and Norway. In Finland the farmers pay part of the costs, and financial grants are also paid by local authorities and dairies. If the farmer has a contract with a veterinarian, the farmer pays the total cost. Development projects in Finland are partly paid through EU funding.

In all countries, the field work is carried out by veterinarians, technicians and local advisory officers.

\section{Scheme Format}

The Swedish and Norwegian herd health schemes have a similar design, with 1) general information to farmers, 2) supervision of the health status, 3) investigation and advisory services in cases of herd problems, and 4) followup of the herd health status. In Denmark the veterinarian must visit contracted farmers at an interval of least 20 and not more than 40 days. Drugs may be handed out to the farmers for continued treatment of diseases diagnosed by a veterinarian if the animal is older than 12 months. Drugs can only be given to herds with a signed service agreement, and the usage must be monitored by the veterinarian. In Finland, schemes and development project vary in design.

The detailed application of all schemes varies from case to case depending on the nature of the herd problem.

The selection of herds is made on the basis of computer printouts (cell count, fertility, dis- 
eases), on the proposal of a veterinarian, or at the direct request of the farmer. In Finland, inquiries are also sent out to the farmers by mail. In Sweden, affiliation can also be recommended by the dairy co-operative.

Parameters used depend on the disease complex. For example, in a herd with mastitis problems it is natural to use the number of cases with clinical mastitis and the cell count in bulk milk or udder total milk samples. Other parameters used are fertility data, clinical disease frequency, and yield.

Goals for animal health improvement can be set up in co-operation with the farmer and read e.g. as cell count. Comparisons can be made with means for groups of herds, for example within a certain geographic region, breed, or herd size. In Sweden, the economic result in a herd and losses caused by diseases can be compiled, based on the annual milk-recording report. The computer programme "Hälsopengen" will be further developed. No economic evaluations are made in Finland. Norway has economic measurements for mastitis, and such measurements will be developed also for other production diseases.

Evaluations of actions taken in a herd are made at intervals as agreed with the farmer, e.g. once annually or at the start and end of the indoor housing period.

400,000 cells $/ \mathrm{ml}$ is an alarm level in bulk milk samples. Herds exceeding this limit are obliged to improve the udder health or they will be excluded from delivering milk to the dairy. The largest dairy co-operative in Sweden has set the limit to 350,000 .

\section{Data Issues}

In Sweden, Denmark, Finland, and Norway, historical data such as cell count, fertility data and disease data from the central database are used as anamnesis.

When visiting a herd, various data are often recorded on barn environment, management routines, and feeding. These data are often only recorded on paper or in a local computer programme, as the Swedish programme "Individjuver". In Denmark the county veterinary officer may study the visit report issued by the visiting veterinarian.

Data collected during herd visit are not regularly published. However, certain case histories are sometimes described.

There is hardly any overlapping of data, but the different records supplement each other.

\section{Current Status}

In Sweden all herds included in the milkrecording scheme ( 86 percent of all herds) receive accounts of reported diseases. In 1998, 423,000 data units were downloaded from the central database in connection with herd investigations carried out by means of the computer programme "Individjuver" (data on the same individual animal can be downloaded several times). Fifty percent of the herds in Denmark have agreements on advisory services. Veterinarians record all diseases in 70 percent of the herds. In 20 percent of the herds most diseases are recorded, whereas recordings are sporadic in the remaining herds. One reason for this variation may be the availability of a computer. In Norway approximately 20,000 dairy herds (89 percent of all herds) are included in the health card system. About 1,200 visits are made within the scope of the Norwegian Cattle Health Services. In Finland disease recording is carried out in 80 percent of the herds, and about 500 herds take part in various projects with animal health programmes.

\section{Swine}

\section{Disease Recording Systems}

Disease recording is mandatory in Sweden and in Denmark. Finland, Norway and Iceland only have compulsory recording of infectious dis- 
eases (according to the OIE classification).

Sweden uses the same system for both cattle and swine. Since 1995, all use of antibiotics in Danish swine production is recorded (preparations, diagnoses, number of animals, age, and identity). Iceland has a disease recording system included in the Agrosoft Pig Recording Database. Some farmers use this system, but there is no central data processing. Finland introduced disease recording via the litter recording in 1983, which is carried out in 20 percent of piglet producing herds. The system can also be used in herds with production of fattening pigs for slaughter. Disease diagnoses, vaccinations, pregnancy tests and health control visits are registered. In Norway, all pig producing herds have a health card for the recording of treated diseases as well as reproductive treatments. Systematic disease recording was carried out by the National Veterinary Authorities in 1990 to 1998 ("RAPP"). Farmer organisations now discuss the design of a new system. The litter recording, "In-Gris", was introduced in 1991 and comprises 50 percent of the sows. Recording of diseases can also be handled by this system.

In Sweden (since the 1960's with the present model), Denmark (since 1925), Finland and Norway, disease recording is also compulsory at meat inspection. In Sweden and Norway recordings are made of abscesses, arthritis, arthrosis, tail-biting, enzootic pneumonia, pleuropneumonia, pleuritis, and so called white spots. In Denmark and Iceland registrations are made of pathological changes in carcasses and organs, which give cause to total or partial condemnation.

Antibiotic therapy in Denmark is recorded by the veterinarian visiting the herd and by the farmer. Also in Finland the drug use is recorded both by the veterinarian and by the farmer. In Norway the health card is kept by the veterinary practitioner. In Sweden, Denmark and Norway, veterinarians and specially trained non-veterinarians are responsible for the registrations at meat inspection.

A national database for the recording of antibiotic usage will be introduced at the National Veterinary Laboratory in Denmark in the year 2000. Presently, these data are stored by veterinarians and farmers. In Finland, the Agricultural Data Processing Centre is responsible for the database as well as for litter recording. The database for infectious diseases in Norway is handled by the National Veterinary Authorities. The breeding organisation Norsvin or the Norwegian Meat Research Centre will probably be responsible for the future database for other diseases. In Sweden, the Swedish Animal Health Service receives quarterly accounts from the slaughterhouses. The Danish Bacon \& Meat Council (DBMC) has access to data from meat inspection, and for this purpose they run a database for their member companies, which cover 95 percent of the production of finishers. Costs involved in the registration of drug usage are defrayed by the farmers. In Finland, the farmer's fee for litter recording also covers costs for disease recording. In Norway, the veterinary authorities pay for the database for infectious diseases. The future database for other diseases will probably be defrayed collectively by the farmers. In Sweden the farmers pay for the recording of diseases. The DBMC bear the costs both for meat inspection and the pertaining database.

\section{Data Input and Feedback Frequency}

In Denmark the use of antibiotics is recorded every month. In Finland, registration and reporting back to the farmers take place as requested two to twelve times a year together with the litter recording report. In Norway, infectious diseases are immediately being reported. The RAPP system involved monthly reports at a regional level. Reporting routines in the future 
system for production diseases have not yet been established. In Denmark, the herd's PRRS status is reported to the farmer every six months, or whenever the status is changed. Danish and Swedish slaughterhouses report meat inspection findings to the farmers within one week. The Swedish Animal Health Service presents quarterly accounts to the farmers. For internal use, the DBMC compiles a monthly national account of inspection findings. In Iceland, a veterinarian specially trained in swine diseases makes recordings of disease findings at the slaughterhouses. These recordings are used in the advisory work and as an instrument to decrease the disease frequency in pig herds. Results from these recordings are sent to the farmers twice a year. In Finland, meat inspection findings at slaughterhouses are reported to the farmers twice a year, and in Norway once quarterly.

Slaughterhouses in Sweden and Denmark are responsible for reporting back to the farmers. In Denmark the responsibility to report antibiotic usage lies on the veterinarian. In Finland, disease reports are compiled by the Agricultural Data Pro-cessing Centre.

Swedish slaughter data are stored for ten years. All data from pig slaughtering within the DBMC have been electronically stored from 1994. National summaries are available for several years back. In Iceland, data from disease recordings from 30 to 50 percent of slaughtered pigs are stored in a database kept by the veterinarian specialising in pig diseases. In Finland data are available from 1983. All disease data in Norway are stored in a central database.

Both for cattle and swine under-coverage may occur, which limits the usability of the records. One contributory cause is the readiness of the farmers to call for a veterinarian in cases of disease; another cause being the fact that treatments carried out by the farmers themselves are not recorded; and a third fact may be the failure of the veterinarian to keep a journal. Certain diagnoses can easily be regarded as "routine", as for instance piglet diarrhoea, and are therefore not reported. Mortality at the production of finishers is not being registered (SE). Evaluations at meat inspection of pigs may vary between slaughterhouses. Furthermore, certain diseases are not registered, e.g. enzootic pneumonia (DK), or they are included in a wider concept, such as pneumonic lesions (SF). In cattle, under-coverage of ketosis, digital diseases, and diseases in calves and young stock are likely to be common.

\section{Herd Health Schemes}

Swedish herd health schemes are based on regulations issued by the National Board of Agriculture. Affiliation is voluntary but necessary for quality assured production. In addition, monitoring programmes are available for a.o. PRRS and salmonella. Affiliation in Denmark to the SPF programme and the PRRS database is voluntary. There are no government regulations. However, infection with PRRS virus is liable to notification. Monitoring of the salmonella status in finishers is run according to government regulations. In Finland, breeding herds are required to be affiliated to a health scheme supervised by veterinary authorities. Herds must be free from enzootic pneumonia, pleuropneumonia, atrophic rhinitis, dysentery, Clostridium perfringens type 1, mange, and a number of diseases, which normally do not exist in this country. In principle, piglet producing herds must be free from the same diseases as the breeding herds. In this way, herds with production of finishers can be kept free from diseases within the scope of voluntary health program-mes. In Iceland, some farmers have voluntarily signed agreements with a veterinary practice for consultation in the field of swine diseases. The Veterinary Services of the Ministry of Agriculture organises screenings for 
various diseases and, if necessary, initiate eradication programmes (Mycoplasma hyopneumoniae, dysentery, mange).

DBMC and Norsvin demand affiliation to a health scheme for breeding herds and multiplying herds. The Norwegian scheme comprises mainly infectious diseases. There is also a voluntary health scheme for all swine herds, which aims at improving the animal health, production quality and production economy. In 1999 the slaughterhouses introduced a new quality system for weaned pigs - "Helsegris". The piglets are to be free from infection with $M y$ coplasma hyopneumoniae, swine dysentery, sarcoptic mange, and atrophic rhinitis. The herds must also meet certain disease control requirements, and the piglets must be delivered directly to the producer of finishers. An annual certificate from the veterinary practitioner is demanded. Herds infected with Mycoplasma hyopneumoniae, but otherwise meet the abovementioned requirements, are allowed to sell piglets as "Primagris/ Samgris".

Health care for breeding herds and piglet producing herds in Sweden dates back to the early 1940's. Health care services for finishers started in 1988. The Danish SPF scheme was launched in 1968. The PRRS database was established in 1996. The Norwegian Pig Health Service started in 1988.

The Danish PRRS database contains data on the herd status. Breeding and multiplying herds are also certified as to their salmonella status. With the aid of the SPF scheme a well defined health status can be maintained with regard to Actinobacillus pleuropneumoniae, Mycoplasma hyopneumoniae, toxin producing Pasteurella multocida, Serpolina hyodysenteriae, Sarcoptes scabei and Haematopinus suis. DBMC demands the breeding and multiplying herds to be registered in the PRRS database. Sow herds wishing to sell their surplus piglets are recommended by the trading organisations to partici- pate in the scheme. In Finland the schemes are aiming at different infectious diseases such as mycoplasma infection, atrophic rhinitis, dysentery, and others.

The Swedish Animal Health Service has the overall responsibility for swine health services in Sweden. A subsidiary company to DBMC handles the SPF programme. The PRRS database is administered by the National Committee for Pig Breeding, Health and Production. Health schemes in Finland are run by the larger slaughterhouses. The Norwegian Pig Health Service is a central organisation, while the health schemes are handled by the regional slaughterhouses.

In Sweden the farmers pay for all costs for affiliation to a health programme. In the SPF scheme the farmers also defray all costs, which vary depending on herd type. Breeding and multiplying herds receive monthly visits. Production herds are visited four times a year. Administration and information pertaining to the PRRS database are paid for by the National Committee for Pig Breeding, Health and Production. The farmers pay for sampling and analyses. In Iceland the farmers pay all expenses for veterinary consultation. In Norway the National Veterinary Authorities cover financially the compulsory programme for breeding and multiplying herds, whereas the voluntary scheme is paid for by the farmers.

Field work in Sweden is carried out by regional veterinarians employed by the Swedish Animal Health Service, who in turn engage experts in the fields of buildings, feeding and breeding. Herd visits in breeding and multiplying herds within the SPF programme are carried out by DBMC personnel. Local veterinarians visit the production herds. In Iceland the veterinary practitioners and the veterinarian specialising in pig diseases take part in field work and advisory services when required. In Finland, veterinarians specialising in swine health and em- 
ployed by the slaughterhouses visit problem herds. Veterinary practitioners, advisory staff from the slaughterhouses, and other advisory officers when needed, are in charge of the Norwegian field work.

\section{Scheme Format}

The Swedish herd health scheme for swine offers the same services to all herds. In the SPF scheme, which also comprises PRRS, the services vary with regard to herd status (SPF, MS [herds infected with Mycoplasma hyopneumoniae] or lower level). Breeding and multiplying herds are also certified with respect to their salmonella status. Veterinarians in Iceland make regular calls to contracted farms in order to discuss problems that might occur and to propose corrective measures in co-operation with the specialised veterinarian. Norway offers different levels of affiliation to swine health schemes:

- a simple format, involving general information to the farmer four times a year, comments on the quarterly reports from meat inspection and a copy of the "In-Gris" annual report to the herd veterinarian;

- another alternative with contracted monthly visits by a veterinarian;

- breeding and multiplying herds get quarterly visits by the official district veterinarian;

- "Helsegris".

Herds in Sweden with production of finishers, and which are among the 10 percent most disease-laden herds for any inspection finding, are flagged, and if the same remark reoccurs during two consecutive quarter periods, the herd is offered advisory services from a veterinarian or other expertise, provided that the herd is affiliated to the Swedish Animal Health Service. Herds refusing visits are reported to the Board of Agriculture, who can order an investigation. In Denmark the farmers receive information about the PRRS database through letters and agricultural magazines. Information on the SPF scheme is given on affiliation. In Norway it generally is the veterinary practitioner or advisory officers from the slaughterhouse who recommend affiliation to herd health schemes.

The health status of Swedish herds with production of finishers is monitored by means of clinical observations and compilations of meat inspection findings. Besides observation of clinical indications of disease in SPF herds, serological tests are performed monthly in breeding and multiplying herds with regard to Actinobacillus pleuropneumoniae (Ap) and Mycoplasma hyopneumoniae (Mh), and by means of nasal swab tests twice a year with a view to the toxin producing Pasteurella multocida. In production herds, serological tests for Ap and Mh are carried out once a year. As for PRRS, breeding and multiplying herds are required to have serological examinations of ten samples each month, and production herds must take 20 samples once a year or an antibody test with regard to PRRS in meat juice in 40 samples over a year. In Norway all diagnoses are used from the health cards, as well as different data depending on herd category from "In-Gris" concerning production, reproduction and health, such as matings, farrowings, living and stillborn pigs, birth weights, weaning, weight at reception and slaughter, feed consumption, data from the quarterly meat inspection reports, and environmental factors registered during the herd visit.

The goal in Sweden is to continuously improve the health situation in flagged herds. The aim of the SPF programme is to keep the herds free from the specified diseases. Breeding and multiplying herds must be free from dysentery and sarcoptes mange, and most of the herds are in the SPF programme. The PRRS database only records the herds' health status. Iceland has set up a five-year plan (ending in 2002), aiming at a national clearance of mange and dysentery. In 
Norway the goal is to attain national freedom from sarcoptes mange in the year 2000, and that certain regions will be freed from infection with Mycoplasma hyopneumoniae in 2002. A general conception is to keep breeding and multiplying herds free from infectious diseases (according to OIE classification) as well as from Mycoplasma hyopneumonia infection, swine dysentery and atrophic rhinitis. Certain disease control requirements must also be met. Similar requirements also exist for vendors of "Helsegris". Individual goals are generally set for other herd categories.

No economic weights have been added for the presence of diseases in a herd.

Clinical indications of diseases in an SPF herd, seroconversions or findings at meat inspection lead to immediate follow-up by a veterinarian in order to verify or cross out suspicion of disease. In cases when control samples turn out positive in a herd free from PRRS, the farmer, the herd veterinarian and the trade organisations are informed. Additional samples are taken to clarify the herd status. In Norwegian breeding and multiplying herds and in herds selling "Helsegris" the certificate is revoked, should any of the specified diseases occur in the herd. A new certificate is not issued until the herd has been cleared from the disease.

\section{Data Issues}

The Swedish health care service for finishers employs historical data for quarter periods and year. Generally, no historical data are used in the SPF scheme. Herds with repeated reinfection and culling are normally unable to have their SPF status renewed. The PRRS database contains herd data, analysis results and changes of the PRRS status. In Iceland the veterinarian uses data from the disease recording as well as meat inspections findings at slaughter. As a rule, there is no co-ordination in Finland between disease data collected via the litter recording system and the health schemes run by the slaughterhouses. The health schemes have their own recordings covering a.o. laboratory results, inspection findings at slaughter, and feeding data. The "In-Gris" herds receive annual herd reports. Periodic reports are produced on request. The quarterly meat inspection report shows the herd's disease incidence together with the slaughterhouse average.

In Sweden written notes are taken on various observations made during herd visits, but a computerised system is presently being evaluated. At health check-ups in SPF herds, indications of clinical diseases are noted together with results from laboratory tests and changes in the production result.

Compilations of data from meat inspection in Sweden are published quarterly, stating means for each slaughterhouse and the variation between herds. Data from the SPF scheme are not regularly published. However, certain case histories are reported, e.g. the frequency of reinfections. The prevalence of PRRS is regularly reported nationally as well as regionally to farmers and veterinarians.

Affiliation to the PRRS database is voluntary. For this reason, disease incidences may be underestimated. The absence of anamneses at samplings may lead to incorrect conclusions as to the health status of the herd. Results from serology and other laboratory tests in the SPF scheme are computer stored. Other data are only available on paper and consequently not as easily accessible. In Norway disease data for 1999 are missing, except for diseases in groups $\mathrm{A}, \mathrm{B}$, and $\mathrm{C}$.

Sweden has 7,400 producers of finishers, 1,400 of which are affiliated to the Swedish Animal Health Service. These herds represent 70 percent of Swedish pig slaughtering. 3,600 herds participate in the SPF programme, corresponding to approximately 20 percent of all Danish pig herds. The PRRS database comprises a to- 
tal of 80 percent of sows and about 60 percent of finishers in Denmark. In Finland, 150 breeding herds and 1,300 piglet producing herds (of totally 2,300) are affiliated to herd health schemes. Approximately 600 out of totally 3,900 Norwegian herds take part in health schemes. Herds with contracted visits are presently few, but the goal is to have 50 percent of the major sow herds and 20 percent of the main producers of finishers affiliated in the year 2000. Breeding and multiplying herds (about 140 to 150 ) are certified. The number of herds approved for "Helsegris" varies between regions, from 0 to 60 percent.

\section{Acknowledgements}

For valuable contributions to this article, the authors wish to convey their sincere thanks to the following persons: In Sweden: Jonas Carlsson, Peter Strandberg, and Martin Wierup; in Denmark: Ole Andersen, Jens Yde Blom and Sten Mortensen; in Iceland: Audur Lilja Arnthorsdottir and Konrad Konradsson; in Finland: Laura Kulkas, Taina Laine and Eero Rautiainen; and in Norway: Børge Baustad.

\section{Reference}

Plym Forshell K, Østerås O, Aagaard K, Kulkas L: Disease recording and cell count data in 1993 in Sweden, Norway, Denmark and Finland. Progress in the control of mastitis. Proc. 3rd Int. Mastitis sem. May 28 - June 1, 1995, Tel Aviv, Israel.

\section{Sammanfattning}

För nötkreatur är sjukdomsregistrering obligatoriskt i Sverige och Norge. Sverige och Danmark har också obligatorisk sjukdomsregistrering för svin, medan det i Finland och Norge endast är obligatoriskt för infektionssjukdomar. Både obligatoriska och frivilliga system är databaserade och har etablerats från 1970talet och framåt. Sjukdomsregistrering vid svinslakt är dock äldre. Både den praktiserande veterinären och oftast även djurägaren kan rapportera till systemen både behandlade sjukdomsfall och fertilitetsstörningar. Sjukdomsregistrering vid slakt utförs av veterinärer och besiktningsassistenter. Databaserna administreras av respektive lands veterinärmyndighet eller av jordbrukets organisationer. Kostnaderna belastar myndigheter och/eller lantbruket. Djurägarna får periodiska redovisningar. Uppgifter i databaserna skall sparas i tre-tio år. Uppgifter lagras dock ofta längre. Anslutning till djurhälsoprogram för nötkreatur respektive svin är frivilligt. De bedrivs i Sverige och Danmark (nöt) inom ramen för statliga föreskrifter. Anslutning till djurhälsoprogram kan också krävas av näringens organisationer. Administration av djurhälsoprogram ligger hos lantbrukets organisationer. Djurägarna svarar själva för kostnaderna att deltaga i ett djurhälsoprogram. Stöd med medel från lantbrukets organisationer, myndigheter, kommuner och EU kan förekomma. 